Research Article

\title{
The Potential to Replace Cement with Nano-Calcium Carbonate and Natural Pozzolans in Cemented Mine Backfill
}

\author{
Mohammed Hefni iD and Maaz A. Ali iD \\ Mining Engineering Department, King Abdulaziz University, Jeddah 21589, Saudi Arabia \\ Correspondence should be addressed to Mohammed Hefni; mhefni@kau.edu.sa
}

Received 6 February 2021; Revised 25 February 2021; Accepted 27 February 2021; Published 9 March 2021

Academic Editor: Lijie Guo

Copyright ( $) 2021$ Mohammed Hefni and Maaz A. Ali. This is an open access article distributed under the Creative Commons Attribution License, which permits unrestricted use, distribution, and reproduction in any medium, provided the original work is properly cited.

\begin{abstract}
The effectiveness of mine backfilling depends on the properties of its constituents. The high cost of cement, which is commonly used as a binder in mine backfill, has led researchers to seek alternatives to partially replace it with other binders. This study investigated the potential to use nano-calcium carbonate (NCC) and natural pozzolans (zeolite and pumice) along with Portland cement (PC) in mine backfill. Two types of experimental samples were prepared: (1) gold tailings and silica sand to investigate the effect of NCC and (2) nickel tailings to investigate the effect of natural pozzolans. The unconfined compressive strength (UCS) was measured for samples cured for up to 56 days. Moreover, selected samples were subject to mercury intrusion porosimetry to investigate microstructural properties. Results show that addition of NCC did not improve the UCS of backfill prepared with gold tailings and cured for 28 days, whereas a dosage of $1 \%$ NCC in backfill samples prepared with silica sand improved UCS by $20 \%$, suggesting that the gold tailings negatively affected strength development. Natural pozzolans, in particular, $20 \%$ zeolite, had $24 \%$ higher UCS after 56 days of curing compared to samples prepared with PC and thus have the potential to partially replace cement in mine backfill.
\end{abstract}

\section{Introduction}

Mine backfilling is the practice of filling underground voids created during ore extraction in underground mining operations to (1) provide stability for the underground working environment [1], (2) reduce negative environmental impacts from tailings' storage on the surface [2-4], and (3) maximize extracted ore volumes, such as in room and pillar mining $[5,6]$. Three common mine backfill materials are rock fill (RF), hydraulic fill (HF), and paste fill (PF) $[1,7-9]$. To make RF, waste rocks from the surface or underground are crushed (typically to $16 \mathrm{~mm}$ ) and possibly cemented, depending on the required strength [10-12]. By decreasing waste rock piles on the surface, adverse environmental impacts and rock subsidence are avoided [11-14]. However, to ensure backfilling efficiency, binder consumption is high [15]. HF is produced during the classification of mill tailings using hydrocyclones: coarse, dense ( $>70 \mathrm{wt}$.\% solids) underflow is obtained [16-19]. The high water content of HF facilitates transport through pipelines directly into stopes $[19,20]$. According to
Adiansyah et al. [21], drainage is the most critical factor in designing HF because ineffective drainage can pose a risk to workers if porous barriers are not used, and piping and liquefaction problems are common. PF consists of mill tailings with $15 \%$ of the material $<20 \mu \mathrm{m}$ in size and solid concentrations of $70-85 \mathrm{wt} . \%[15,22,23]$. The high solids and low water content can cause issues for transport through pipelines and necessitate addition of a superplasticizer to enhance flowability $[24,25]$.

Mine tailings are waste products from ore concentration in mineral processing plants [26]. Their chemical and physical properties must be considered during backfill design because they can affect backfill mechanical properties [27]. For instance, tailings that contain sulfide minerals are prone to sulfate attack, which can decrease the unconfined compressive strength (UCS) over the long term due to ettringite formation [28]. Thus, binders that are compatible with the tailings are added to backfill at low concentrations to enhance UCS and other mechanical properties [29]. Cement is typically the main binder, but it is expensive. Therefore, alternative binders are required [30]. 
Recent advances in nanotechnology have presented the opportunity to use nanomaterials as supplementary cementitious materials [31]. The fine particles act as nuclei for cement to accelerate hydration and improve UCS at early stages [32]. Nano-silica, carbon nanotube, and nano-calcium carbonate (NCC) have been shown to increase cement base material strength [33-35]. For example, adding NCC to cement and silica fume accelerated the pozzolanic reaction at an early age and compensated for the low initial strength $[36,37]$.

Supplementary cementitious materials such as natural (e.g., volcanic pumice and zeolite) and artificial pozzolans (e.g., fly ash) could partially replace cement to prevent sulfate attack $[38,39]$. Pozzolanic materials in mine backfill can reduce binder costs by more than $15 \%$ on an annual basis [30, 40-42]. At concentrations ranging from 10 to $30 \%$, natural pozzolans improved concrete mechanical properties, permeability, durability, and transport properties [43-46]. Volcanic pumice properties vary by source and location due to different ash formation conditions, mineral components, and grain size characteristics [47-49]. Addition of zeolite enhanced the mechanical properties, durability, and performance of concrete [50-53]. Many industrial wastes also have pozzolanic properties [54]. For example, clay pozzolans, produced through calcination at temperatures ranging from 700 to $900^{\circ} \mathrm{C}[2,55]$, are inexpensive, have low $\mathrm{CO}_{2}$ emissions compared to cement, and improve backfill mechanical properties $[56,57]$. Addition of $10 \%$ clay pozzolans to mine backfill produced maximum UCS and an annual savings of $>7 \%[2,58]$.

The application of NCC and natural pozzolans has primarily focused on concrete production: possible effects on backfill mechanical properties have not yet been widely investigated. Therefore, this paper investigates partial replacement of cement by NCC, pumice, or zeolite in cemented mine backfill. To investigate the effect of NCC, backfill samples were prepared with gold tailings and a superplasticizer to aid nanoparticle dispersion: various dosages of NCC were compared with reference samples containing only Portland cement (PC). To investigate the effect of natural pozzolans, backfill samples were prepared with nickel tailings and various dosages of pumice and zeolite were compared against reference samples containing PC only or a combination of PC and fly ash. Samples were subject to UCS tests after up to 56 days of curing and selected samples were subjected to mercury intrusion porosimetry to investigate microstructural properties.

\section{Methods}

2.1. Materials. Tailings from gold and nickel mines and silica sand were used to make experimental backfill samples (Table 1). The particle size distribution (PSD) of these materials is shown in Figure 1.

The chemical composition of Type 10 PC with a specific gravity of 3.15, pumice (provided by Hess Pumice Company) with a specific gravity of 2.35 , zeolite (provided by Bear River Zeolite), and fly ash are shown in Table 2 . The chemical and physical properties of the NCC (provided by US Research Nanomaterials, Inc.) are shown in Table 3.
TABLE 1: Mineralogy and physical properties of silica sand and two types of tailings ( $\%$ by weight).

\begin{tabular}{lccc}
\hline Characteristic & Gold tailings & $\begin{array}{c}\text { Nickel } \\
\text { tailings }\end{array}$ & $\begin{array}{c}\text { Silica } \\
\text { sand }\end{array}$ \\
\hline Mineralogy (wt.\%) & 49.02 & 77.28 & - \\
$\mathrm{SiO}_{2}$ & 17.68 & 11.09 & - \\
$\mathrm{Al}_{2} \mathrm{O}_{3}$ & 9.15 & 2.13 & - \\
$\mathrm{Fe}_{2} \mathrm{O}_{3}$ & 7.29 & - & - \\
$\mathrm{SO}_{3}$ & 6.52 & 2.22 & - \\
$\mathrm{CaO}$ & 3.79 & 1.14 & - \\
$\mathrm{MgO}$ & 2.70 & 2.19 & - \\
$\mathrm{K}_{2} \mathrm{O}$ & 0.64 & 0.27 & - \\
$\mathrm{TiO}{ }_{2}$ & & & \\
$\mathrm{Physical} \mathrm{properties}$ & 2.89 & 2.80 & 2.69 \\
$\mathrm{Specific}$ gravity & 35.22 & 3.54 & 20.14 \\
$\mathrm{D} 10(\mu \mathrm{m})$ & 75.37 & 82.05 & 48.03 \\
$\mathrm{D} 30(\mu \mathrm{m})$ & 97.72 & 9.92 & 75.60 \\
$\mathrm{D} 50(\mu \mathrm{m})$ & 105.78 & 170.55 & 88.65 \\
$\mathrm{D} 60(\mu \mathrm{m})$ & 200.09 & 189.66 & 185.95 \\
$\mathrm{D} 90(\mu \mathrm{m})$ & 3.003 & 48.177 & 4.407 \\
$\mathrm{Cu}(\mathrm{D} 60 / \mathrm{D} 10)$ & 1.52 & 11.15 & 1.29 \\
$\mathrm{Cc}\left(\mathrm{D} 30^{2} /(\mathrm{D} 10 \times \mathrm{D} 60)\right)$ & & & \\
\hline
\end{tabular}

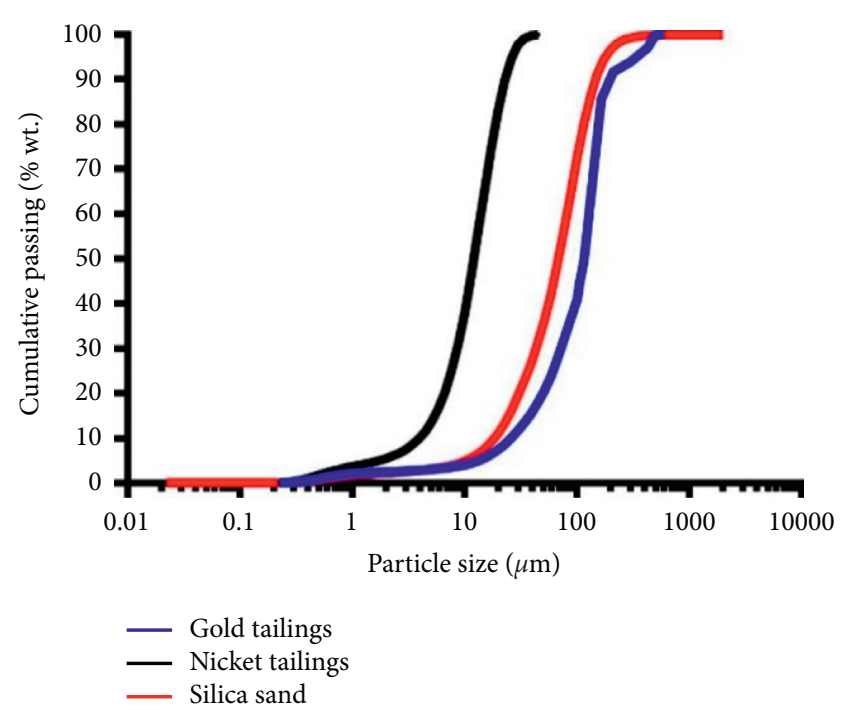

FIgure 1: Particle size distribution of gold and nickel tailings and silica sand.

NCC is characterized by high energy and surface area; thus, surface reactions occur, and particles are prone to adhere on direct contact via magnetic, electrostatic, and Van der Waals forces [37]. To aid NCC dispersion, a superplasticizer (sodium dodecyl sulfate, Thermo Scientific Company) was used, with the chemical and physical properties listed in Table 4.

Tap water ( $\mathrm{pH}$ 7.5) was used to prepare experimental backfill samples. Compounds in mixing water can influence the mechanical properties of backfill and cement hydration [59]. For instance, dissolved calcium and magnesium enhance cement hydration, whereas salty brine decreases binder workability [60]. 
Table 2: Chemical composition of Portland cement and supplementary cementitious materials (wt.\%).

\begin{tabular}{lccccccccc}
\hline Material & $\mathrm{CaO}$ & $\mathrm{Al}_{2} \mathrm{O}_{3}$ & $\mathrm{SiO}_{2}$ & $\mathrm{MgO}$ & $\mathrm{Fe}_{2} \mathrm{O}_{3}$ & $\mathrm{TiO}_{2}$ & $\mathrm{Na}_{2} \mathrm{O}$ & $\mathrm{K}_{2} \mathrm{O}$ & $\mathrm{SO}_{3}$ \\
\hline Portland cement & 61.14 & 4.6 & 19.38 & 3.35 & 2.02 & - & 2.03 & 0.71 & 2.28 \\
Pumice & 0.8 & 13.5 & 76.2 & 0.05 & 1.1 & 0.2 & 1.6 & 1.8 \\
Zeolite & 5.6 & 3.5 & 70.3 & - & 3.05 & - & 4.7 & 3.8 \\
Fly ash & 5.02 & 20 & 41.22 & 1.4 & 23.84 & - & 0.81 & 1.5 \\
\hline
\end{tabular}

TABLE 3: Chemical and physical properties of nano-calcium carbonate.

\begin{tabular}{lccccc}
\hline Appearance & $\mathrm{CaCO}_{3}(\%)$ & $\mathrm{HCl}$ insoluble $(\%)$ & Particle size $(\mathrm{nm})$ & $\mathrm{Fe}(\%)$ & $\mathrm{Mn}(\%)$ \\
\hline White powder & $\geq 98$ & $\leq 0.1$ & $20-50$ & $\leq 0.08$ & $\leq 0.006$ \\
\hline
\end{tabular}

TABle 4: Chemical and physical properties of the sodium dodecyl sulfate superplasticizer.

\begin{tabular}{lcccc}
\hline Appearance & Concentration $(\%)$ & Density $\left(\mathrm{g} / \mathrm{cm}^{3}\right)$ & $\mathrm{pH}$ & Boiling point $\left({ }^{\circ} \mathrm{C}\right)$ \\
\hline Liquid & $73-79$ & 1.08 & $5-7$ & 78 \\
\hline
\end{tabular}

2.2. Experimental Design. Backfill samples containing NCC were prepared with 7 wt.\% (by weight of dry materials) PC as a binder and $78 \%$ solids' concentration using gold tailings (Table 5). Mixtures of PC and 1,3, and 5\% NCC (by dry weight of PC, equation (1)) were initially dry mixed to break up agglomerated nanoparticles that were visible to the naked eye. Dried tailings were then added, and water was gradually added to the mixture to make a paste. Finally, superplasticizer was added (by dry weight of NCC, equation (2)). Samples were poured into $5.08 \times 10.16 \mathrm{~cm}$ cylindrical molds and cured for 7,14 , and 28 days at $25 \pm 2^{\circ} \mathrm{C}$ and $90 \pm 2 \%$ relative humidity:

$$
\begin{aligned}
M_{\mathrm{NCC}} & =D_{\mathrm{NCC}} \times M_{\mathrm{PC}}, \\
M_{\mathrm{SP}} & =D_{\mathrm{SP}} \times M_{\mathrm{NCC}},
\end{aligned}
$$

where $M_{\mathrm{NCC}}$ is the mass of NCC $(\mathrm{g}), D_{\mathrm{NCC}}$ is the dosage of NCC (\%), $M_{\mathrm{PC}}$ is the mass of PC $(\mathrm{g}), M_{\mathrm{SP}}$ is the mass of superplasticizer $(\mathrm{g})$, and $D_{\mathrm{SP}}$ is the dosage of the superplasticizer (\%).

Backfill samples containing 10 and $20 \%$ pumice, zeolite, or fly ash were prepared using nickel tailings and PC with a solid concentration of $80 \%$ (Table 6 ; equations (3) and (4)). Samples were cured for $7,14,28$, and 56 days at $25 \pm 2{ }^{\circ} \mathrm{C}$ and $90 \pm 2 \%$ relative humidity:

$$
\begin{aligned}
D_{\mathrm{PC}} & =\frac{M_{\mathrm{PC}}}{M_{\mathrm{PC}}+M_{\mathrm{T}}}, \\
M_{\mathrm{POZ}} & =R \times M_{\mathrm{PC}},
\end{aligned}
$$

where $D_{\mathrm{PC}}$ is the dosage of PC (\%), $M_{\mathrm{T}}$ is the mass of tailings (g), $M_{\mathrm{POZ}}$ is the mass of pozzolans $(\mathrm{g})$, and $R$ is the percentage of PC replaced by pumice, zeolite, or fly ash (\%).

2.3. Unconfined Compressive Strength. On each curing date, the UCS of triplicate cured backfill samples was measured on a Wykeham Farrance $100 \mathrm{kN}$ loading machine with a $50 \mathrm{kN}$ load cell after ASTM D2166/D2166M-16 [61] (Figure 2). UCS values are reported as means.
2.4. Mercury Intrusion Porosimetry. Mercury intrusion porosimetry (MIP after ASTM D4404-18 [62]) was used to describe the pore structure of select backfill samples made with $20 \%$ pumice, zeolite, and fly ash after 56 days of curing (Table 6). The macrosize and volume distribution of pores inside materials are commonly measured using MIP, which is a well-known technique, although it has adverse environmental effects.

\section{Results and Discussion}

3.1. NCC Backfill Samples. The mean UCS of backfill samples increased with curing time at all NCC dosages and was consistently higher in reference samples than those made with 1\% NCC and 10-100\% superplasticizer (Figure 3), 3\% NCC and $10-80 \%$ superplasticizer (Figure 4), or 5\% NCC and $10-30 \%$ superplasticizer (Figure 5). Thus, the maximum UCS was observed for reference samples on day 28 $(\sim 0.80 \mathrm{MPa})$. The differences between treatment and reference sample means became more pronounced with NCC content, such that, on day 28 , the UCS of the $30 \%$ superplasticizer sample was 5\% (Figure 3), 25\% (Figure 4), and $36 \%$ (Figure 5) lower for the 1,3, and 5\% NCC samples, respectively. At 1 and 5\% NCC, addition of superplasticizer had a negative effect on UCS on each curing date ( Figures 3 and 5), but at $3 \%$ NCC, it had a positive effect on UCS (Figure 4).

Figure 6 shows the samples with the maximum UCS on each curing day for 1,3 , and 5\% NCC. Relative to the reference sample, increasing NCC from 1 to $5 \%$ decreased the UCS of backfill samples by $24-56 \%$ on day $7,3-32 \%$ on day 14 , and $5-30 \%$ on day 28 .

Since adding NCC did not improve the UCS of backfill samples, the gold tailings were replaced with a more neutral material to see if the loss of strength was due to an interaction between the tailings and the NCC. Samples prepared with silica sand augmented with $7 \%$ PC or $7 \%$ PC $+1 \%$ NCC were tested for UCS. The UCS increased with curing time as above (Figure 7). Addition of $1 \%$ NCC increased the UCS from 0.71 to $0.82 \mathrm{MPa}$ by day 7 , did not affect UCS on day 14 , and by day 28 , increased the UCS 
TABle 5: Mixing design for all backfill samples containing nano-calcium carbonate.

\begin{tabular}{lccc}
\hline Mixture ID & Portland cement (\%) & Nano-calcium carbonate (\%) & Superplasticizer (\%) \\
\hline Reference & 7 & 0 & 0 \\
1NCC & 7 & 1 & 0 \\
1NCC10SP & 7 & 1 & 10 \\
NNCC20SP & 7 & 1 & 20 \\
1NCC30SP & 7 & 1 & 30 \\
1NCC40SP & 7 & 1 & 40 \\
1NCC50SP & 7 & 1 & 50 \\
1NCC100SP & 7 & 1 & 100 \\
3NCC & 7 & 3 & 0 \\
3NCC30SP & 7 & 3 & 30 \\
3NCC40SP & 7 & 3 & 40 \\
3NCC50SP & 7 & 3 & 50 \\
3NCC60SP & 7 & 3 & 60 \\
3NCC80SP & 7 & 3 & 80 \\
5NCC10SP & 7 & 5 & 10 \\
5 NCC20SP & 7 & 5 & 20 \\
5NCC30SP & 7 & 5 & 30 \\
\hline
\end{tabular}

TABLE 6: Mixing design for all backfill samples containing natural pozzolans.

\begin{tabular}{|c|c|c|c|c|c|c|}
\hline Mixture ID & Tailings (kg) & Portland cement (g) & Tap water $(\mathrm{g})$ & Pumice $(\mathrm{g})$ & Zeolite (g) & Fly ash $(g)$ \\
\hline Reference & 2.5 & 131.6 & 657.9 & 0 & 0 & 0 \\
\hline FA10 & 2.5 & 118.4 & 657.9 & 0 & 0 & 13.2 \\
\hline FA20 & 2.5 & 105.3 & 657.9 & 0 & 0 & 26.3 \\
\hline PU10 & 2.5 & 118.4 & 657.9 & 13.2 & 0 & 0 \\
\hline PU20 & 2.5 & 105.3 & 657.9 & 26.3 & 0 & 0 \\
\hline ZE10 & 2.5 & 118.4 & 657.9 & 0 & 13.2 & 0 \\
\hline ZE20 & 2.5 & 105.3 & 657.9 & 0 & 26.3 & 0 \\
\hline
\end{tabular}

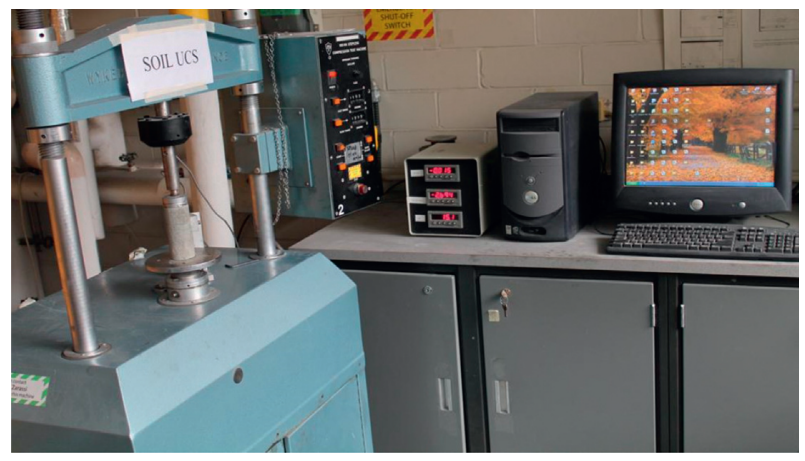

FIGURE 2: Experimental setup for unconfined compressive strength tests.

from 1.0 to $1.2 \mathrm{MPa}$. Silica sand had a higher PSD than gold tailings (Figure 1), which might contribute to the effectiveness of NCC. Previous studies have shown that NCC increased the UCS of concrete mixtures. Concrete has larger and relatively neutral in-earth components compared to backfill tailings. It is believed that physical (PSD) and chemical (components) differences contribute to NCC efficiency early in UCS development.

3.2. Natural Pozzolan Backfill Samples. As with the NCC experiments, the UCS increased with curing time from 7 to 56 days (Figure 8), whereas reference samples had the highest UCS on day 14, and backfill samples prepared with

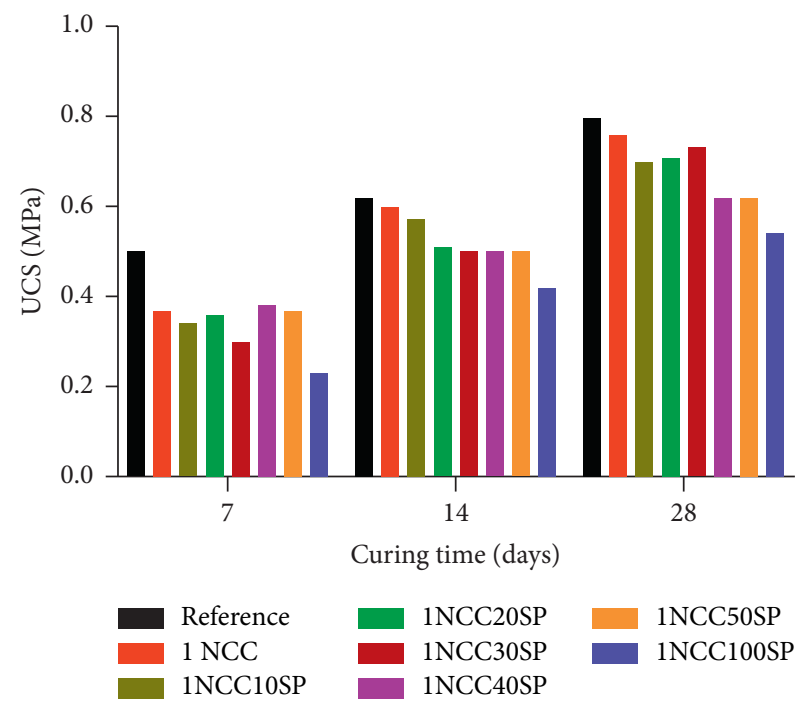

FIgURE 3: Mean unconfined compressive strength (UCS) for triplicate backfill samples prepared with $1 \%$ nano-calcium carbonate (NCC) and 0-100\% superplasticizer (SP). See Table 5, for mixture designs.

$20 \%$ zeolite or $10 \%$ fly ash after 56 days of curing had the highest UCS $(0.66 \mathrm{MPa}), 24 \%$ higher than the reference UCS on that day.

The porosity and pore size distribution of samples containing 20\% pumice, zeolite, and fly ash are shown in Figures 9 and 10, respectively. Samples containing 20\% fly 


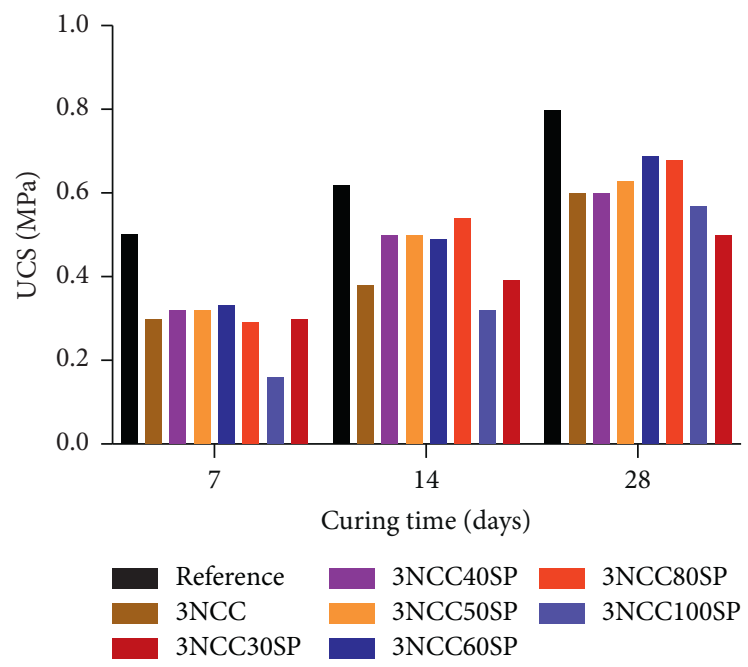

FIGURE 4: Mean unconfined compressive strength (UCS) for triplicate backfill samples prepared with 3\% nano-calcium carbonate (NCC) and $0-100 \%$ superplasticizer (SP). See Table 5, for mixture designs.

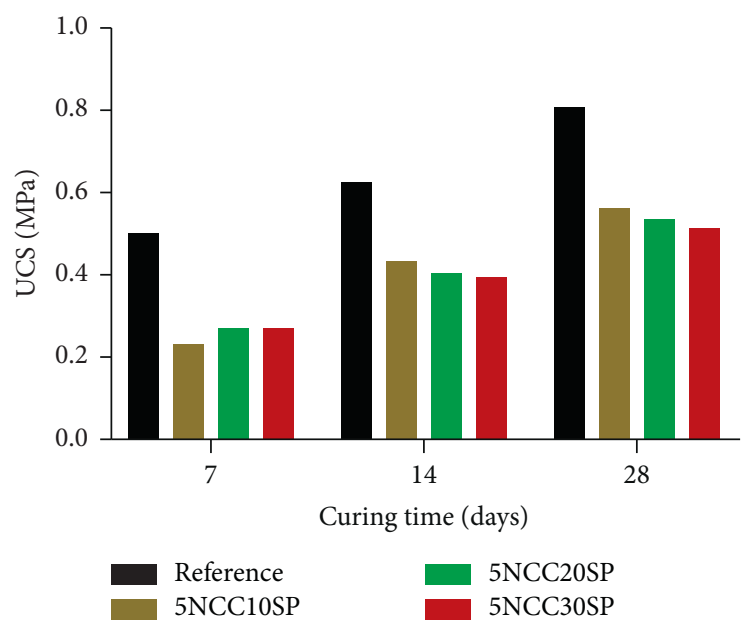

FIGURE 5: Mean unconfined compressive strength (UCS) for triplicate backfill samples prepared with 5\% nano-calcium carbonate (NCC) and $0-30 \%$ superplasticizer (SP). See Table 5 , for mixture designs.

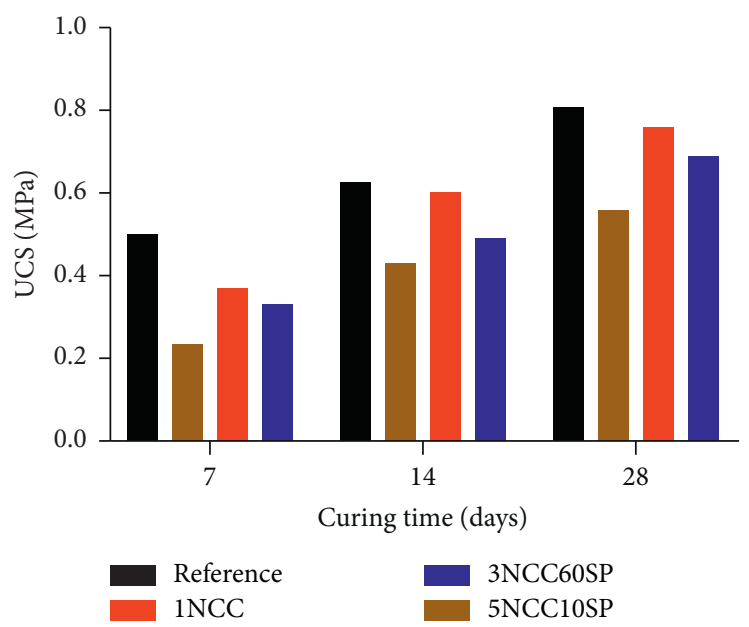

FIGURE 6: Maximum unconfined compressive strength (UCS) for backfill samples prepared with 0 (reference), 1, 3, and 5\% nano-calcium carbonate (NCC) and 0, 10, and 60\% superplasticizer (SP). See Table 5, for mixture designs. 


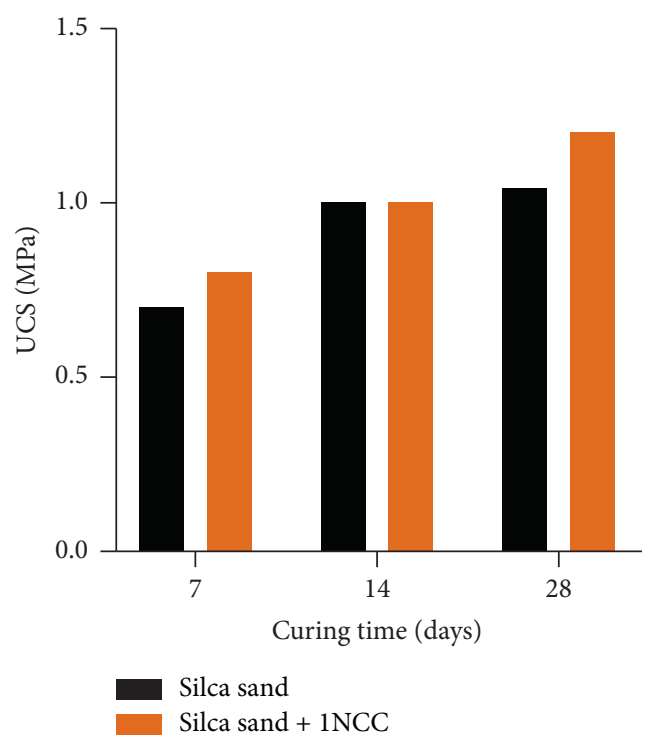

Figure 7: Mean unconfined compressive strength (UCS) of triplicate backfill samples prepared with silica sand without and with $1 \%$ nanocalcium carbonate (NCC). See Table 5, for the NCC mixture design.

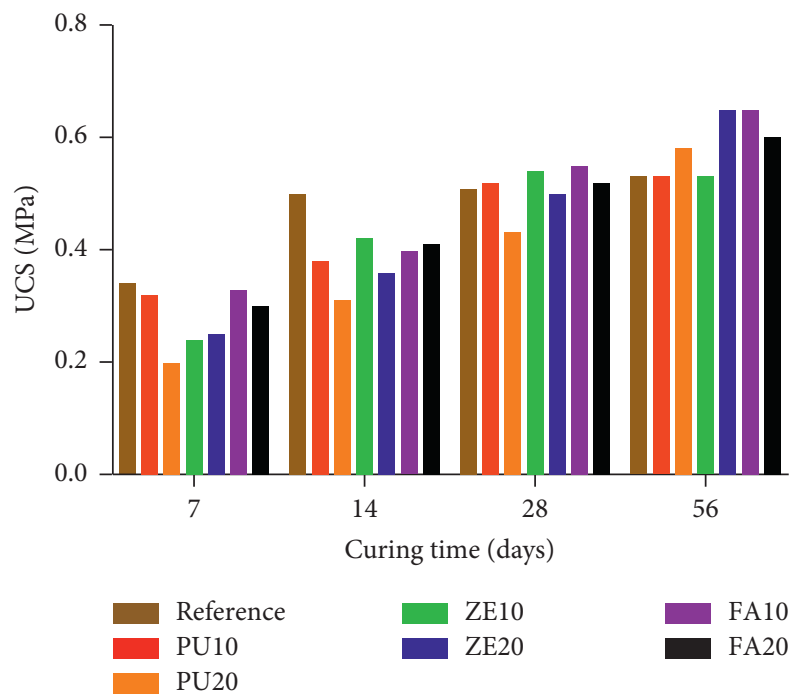

FIGURE 8: Mean unconfined compressive strength (UCS) for backfill samples prepared without (reference) and with 10 and $20 \%$ fly ash (FA), pumice (PU), and zeolite (ZE). See Table 6, for mixture designs.

ash had higher porosity $(\sim 33 \%)$ compared to samples containing natural pozzolans $(\sim 31 \%)$. This could explain the lower UCS value obtained for samples containing fly ash after 56 days of curing (Figure 8). Samples containing fly ash and natural pozzolans had similar range of pore size $(\sim 0.006-10 \mu \mathrm{m})$, as shown in Figure 10. Adding $20 \%$ natural pozzolans decreased the number of pores, especially in the range of $0.01-0.02 \mu \mathrm{m}$ (Figure 10). 


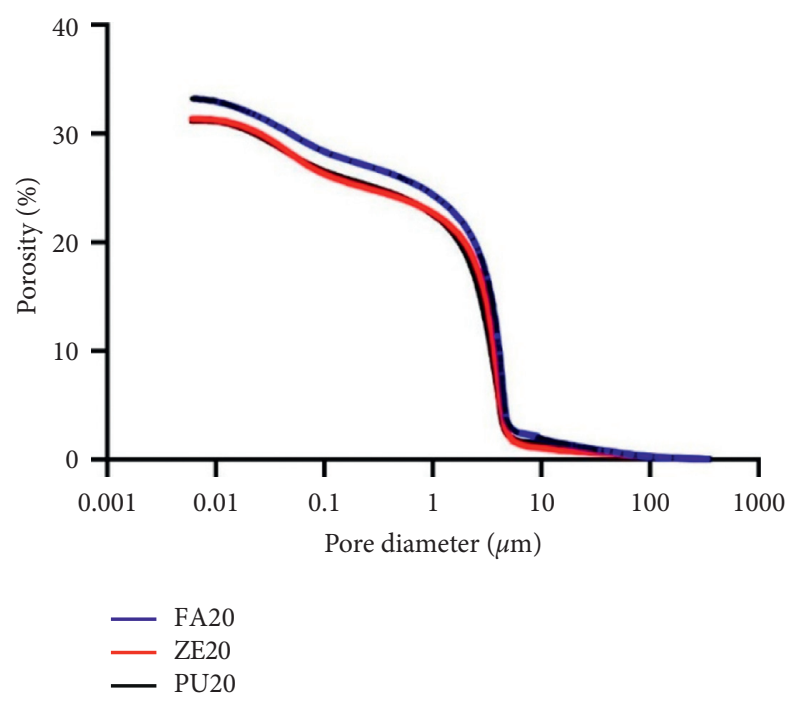

FIGURE 9: Cumulative porosity of natural pozzolans samples.

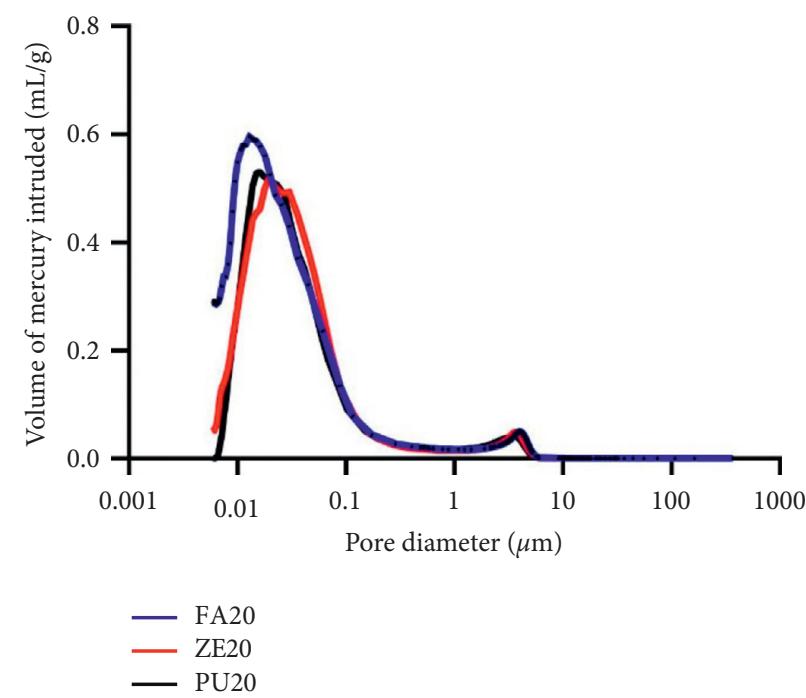

FIGURE 10: The volume of mercury intruded in natural pozzolans samples.

\section{Conclusions}

This study investigated the potential replacement of cement by NCC and natural pozzolans in cemented mine backfill. Key conclusions are summarized as follows:

(i) Addition of NCC did not improve UCS relative to reference samples prepared with PC and gold tailings

(ii) $1 \%$ NCC without superplasticizer yielded the highest UCS among the experimental samples

(iii) Samples containing silica sand instead of gold tailings improved UCC, suggesting that the gold tailings had a negative effect on strength development

(iv) Addition of superplasticizer to NCC samples did not improve the UCS (v) Natural pozzolans may have some potential to partially replace cement in mine backfill

(vi) Addition of $20 \%$ zeolite or $10 \%$ fly ash improved UCS the most on day 56 (24\%) relative to the reference sample

(vii) Samples prepared with $20 \%$ natural pozzolans had a similar pore size distribution $(\sim 0.006-100 \mu \mathrm{m})$ and porosity

(viii) Additional studies are required to examine the effect of particle size and chemistry on the UCS of backfill samples prepared with NCC

\section{Data Availability}

The data used to support the findings of the study are available within the article. 


\section{Conflicts of Interest}

The authors declare no conflicts of interest.

\section{Acknowledgments}

This project was supported by the Deanship of Scientific Research (DSR), King Abdulaziz University, Jeddah, under Grant No. G:196-135-1442. The authors, therefore, gratefully acknowledge the DSR technical and financial support.

\section{References}

[1] M. Sheshpari, "A review of underground mine backfilling methods with emphasis on cemented paste backfill," Electronic Journal of Geotechnical Engineering, vol. 20, no. 13, pp. 5183-5208, 2015.

[2] S. N. Eshun, S. S. R. Gidigasu, and S. K. Y. Gawu, "The effect of clay pozzolana-cement-composite on the strength development of a hydraulic backfill," Ghana Mining Journal, vol. 18, no. 1, pp. 32-38, 2018.

[3] Y. Yao, Z. Cui, and R. Wu, "Development and challenges on mining backfill technology," Journal of Materials Science Research, vol. 1, no. 4, 2012.

[4] T. Belem and M. Benzaazoua, "Design and application of underground mine paste backfill technology," Geotechnical and Geological Engineering, vol. 26, pp. 147-174, 2008.

[5] E. Yilmaz, B. Ercikdi, A. Kesimal, M. Yumlu, and K. Karaoglu, "The application of high density paste backfill at an underground mine," in Proceedings of the 5th International Scientific Conference of Modern Management of Mine Producing, Geology and Environmental Protection, Varna, Bulgaria, June 2005.

[6] B. S. Choudhary, "Paste filling-an overview to improve the quality of filling material," Journal of Mines, Metals and Fuels, 2015.

[7] M. Z. Emad, H. Mitri, and C. Kelly, "State-of-the-art review of backfill practices for sublevel stoping system," International Journal of Mining, Reclamation and Environment, vol. 29, no. 6, pp. 544-556, 2015.

[8] M. Bloss, "An operational perspective of mine backfill," in Proceedings of the Eleventh International Symposium on Mining with Backfill, May 2014.

[9] M. Hefni and F. Hassani, "Experimental development of a novel mine backfill material: foam mine fill," Minerals, vol. 10, no. 6 , p. 564, 2020.

[10] N. J. F. Koupouli, T. Belem, P. Rivard, and H. Effenguet, "Direct shear tests on cemented paste backfill-rock wall and cemented paste backfill-backfill interfaces," Journal of Rock Mechanics and Geotechnical Engineering, vol. 8, no. 4, pp. 472-479, 2016.

[11] W. Sun, H. Wang, and K. Hou, "Control of waste rock-tailings paste backfill for active mining subsidence areas," Journal of Cleaner Production, vol. 171, pp. 567-579, 2018.

[12] D. M. Franks, D. V. Boger, C. M. Côte, and D. R. Mulligan, "Sustainable development principles for the disposal of mining and mineral processing wastes," Resources Policy, vol. 36, no. 2, pp. 114-122, 2011.

[13] L. J. Guo, K. P. Zhou, X. C. Yang, G. S. Liu, and W. Y. Xu, “An experimental study on the mechanical properties of cemented rock-tailings fill," Advanced Materials Research, vol. 941-944, pp. 2611-2619, 2014.
[14] J. C. Wilson, S. Benbow, and R. Metcalfe, "Reactive transport modelling of a cement backfill for radioactive waste disposal," Cement and Concrete Research, vol. 111, pp. 81-93, 2018.

[15] G. Swan and R. Brummer, "Backfill design for deep, underhand drift-and-fill mining," in Proceedings of the Seventh International Symposium on Mining with Backfill MINEFILL 2001, Seattle, WA, USA, 2001.

[16] N. Sivakugan, R. Veenstra, and N. Naguleswaran, "Underground mine backfilling in Australia using paste fills and hydraulic fills," International Journal of Geosynthetics and Ground Engineering, vol. 1, no. 2, 2015.

[17] M. Fahey, M. Helinski, and A. Fourie, "Some aspects of the mechanics of arching in backfilled stopes," Canadian Geotechnical Journal, vol. 46, no. 11, p. 1322, 2009.

[18] M. Fall, M. Benzaazoua, and E. G. Saa, "Mix proportioning of underground cemented tailings backfill," Tunnelling and Underground Space Technology, vol. 23, no. 1, pp. 80-90, 2008.

[19] L. Li, "Generalized solution for mining backfill design," International Journal of Geomechanics, vol. 14, no. 3, 2014.

[20] L. Li and M. Aubertin, "An improved method to assess the required strength of cemented backfill in underground stopes with an open face," International Journal of Mining Science and Technology, vol. 24, no. 4, pp. 549-558, 2014.

[21] J. S. Adiansyah, M. Rosano, S. Vink, and G. Keir, “A framework for a sustainable approach to mine tailings management: disposal strategies," Journal of Cleaner Production, vol. 108, pp. 1050-1062, 2015.

[22] G. Blight, "Mine waste: a brief overview of origins, quantities, and methods of storage," in Waste, 2011, ISBN 9780123814753.

[23] J. Alcott, D. Dallaire, and T. Belem, "Pastefill optimisation at hecla québec's casa berardi mine," in Proceedings of the 53rd U.S. Rock Mechanics/Geomechanics Symposium, American Rock Mechanics Association, New York, NY, USA, June 2019.

[24] G. Chancellor and J. Gonzalez, "Implementation of pastefill at the barrick goldstrike mine," in Proceedings of the 2015 SME Annual Conference and Expo and CMA 117th National Western Mining Conference-Mining: Navigating the Global Waters, Denver, CO, USA, February 2015.

[25] M. J. Raffaldi, J. B. Seymour, J. Richardson, E. Zahl, and M. Board, "Cemented paste backfill geomechanics at a narrow-vein underhand cut-and-fill mine," Rock Mechanics and Rock Engineering, vol. 52, no. 12, pp. 4925-4940, 2019.

[26] E. Yilmaz and M. Fall, Paste Tailings Management, Springer, Cham, Switzerland, 2017, ISBN 9783319396828.

[27] N. Sivakugan, R. M. Rankine, K. J. Rankine, and K. S. Rankine, "Geotechnical considerations in mine backfilling in Australia," Journal of Cleaner Production, vol. 14, no. 12-13, pp. 1168-1175, 2006.

[28] N. Niroshan, N. Sivakugan, and R. Veenstra, "Effects of Different Binders on the Strength and Stiffness of Paste Fills," in Proceedings of the Fourth Geo-China International Conference, July 2016.

[29] A. Kesimal, E. Yilmaz, B. Ercikdi, I. Alp, and H. Deveci, "Effect of properties of tailings and binder on the short-and longterm strength and stability of cemented paste backfill," $M a$ terials Letters, vol. 59, no. 28, pp. 3703-3709, 2005.

[30] B. Ercikdi, F. Cihangir, A. Kesimal, H. Deveci, and Ì. Alp, "Effect of natural pozzolans as mineral admixture on the performance of cemented-paste backfill of sulphide-rich tailings," Waste Management \& Research, vol. 28, no. 5, p. 430, 2010.

[31] S. Parveen, S. Rana, and R. Fangueiro, "A review on nanomaterial dispersion, microstructure, and mechanical properties of carbon nanotube and nanofiber reinforced 
cementitious composites," Journal of Nanomaterials, vol. 2013, Article ID 710175, 2013.

[32] S. Parveen, S. Rana, R. Fangueiro, and M. C. Paiva, "Microstructure and mechanical properties of carbon nanotube reinforced cementitious composites developed using a novel dispersion technique," Cement and Concrete Research, vol. 73, pp. 215-227, 2015.

[33] T. Sato and J. J. Beaudoin, "Effect of nano- $\mathrm{CaCO}_{3}$ on hydration of cement containing supplementary cementitious materials," Advances in Cement Research, vol. 23, no. 1, pp. 33-43, 2011.

[34] S. Chuah, Z. Pan, J. G. Sanjayan, C. M. Wang, and W. H. Duan, "Nano reinforced cement and concrete composites and new perspective from graphene oxide," Construction and Building Materials, vol. 73, pp. 113-124, 2014.

[35] L. P. Singh, S. R. Karade, S. K. Bhattacharyya, M. M. Yousuf, and S. Ahalawat, "Beneficial role of nanosilica in cement based materials - a review," Construction and Building Materials, vol. 47, pp. 1069-1077, 2013.

[36] F. U. A. Shaikh and S. W. M. Supit, "Mechanical and durability properties of high volume fly ash (HVFA) concrete containing calcium carbonate $\left(\mathrm{CaCO}_{3}\right)$ nanoparticles," Construction and Building Materials, vol. 70, pp. 309-321, 2014.

[37] S. Kawashima, J.-W. T. Seo, D. Corr, M. C. Hersam, and S. P. Shah, "Dispersion of $\mathrm{CaCO}_{3}$ nanoparticles by sonication and surfactant treatment for application in fly ash-cement systems," Materials and Structures, vol. 47, no. 6, pp. 1011-1023, 2014.

[38] A. Kesimal, E. Yilmaz, and B. Ercikdi, "Evaluation of paste backfill mixtures consisting of sulphide-rich mill tailings and varying cement contents," Cement and Concrete Research, vol. 34, no. 10, pp. 1817-1822, 2004.

[39] T. Raghavendra, Y. H. Siddanagouda, F. Jawad, C. Y. Adarsha, and B. C. Udayashankar, "Performance of ternary binder blend containing cement, waste gypsum wall boards and blast furnace slag in CLSM," Procedia Engineering, vol. 145, pp. 104-111, 2016.

[40] B. Ercikdi, F. Cihangir, A. Kesimal, H. Deveci, and I. Alp, "The effect of natural pozzolan properties on the strength and stability of paste backfill," Earth Sciences, vol. 29, pp. 25-35, 2008.

[41] O. Peyronnard and M. Benzaazoua, "Alternative by-product based binders for cemented mine backfill: recipes optimisation using Taguchi method," Minerals Engineering, vol. 29, pp. 28-38, 2012.

[42] A. Sargeant, E. De Souza, and J. F. Archibald, "The use of glass as Pozzolan in Backfill binder recipes," in Proceedings of the 42nd U.S. Rock Mechanics Symposium, San Francisco, CA, USA, June 2008.

[43] A. M. Zeyad, B. A. Tayeh, and M. O. Yusuf, "Strength and transport characteristics of volcanic pumice powder based high strength concrete," Construction and Building Materials, vol. 216, pp. 314-324, 2019.

[44] A. M. Zeyad, A. H. Khan, and B. A. Tayeh, "Durability and strength characteristics of high-strength concrete incorporated with volcanic pumice powder and polypropylene fibers," Journal of Materials Research and Technology, vol. 9, no. 1, p. 806, 2020.

[45] L. Yu, H. Ou, and S. Zhou, "Application of high performance concrete with compound admixtures of fly ash and perlite powder in pavement of highway," Advanced Materials Research, vol. 413, 2012.
[46] K. M. A. Hossain, S. Ahmed, and M. Lachemi, "Lightweight concrete incorporating pumice based blended cement and aggregate: mechanical and durability characteristics," Construction and Building Materials, vol. 25, no. 3, p. 1186, 2011.

[47] B. Y. Pekmezci and S. Akyüz, "Optimum usage of a natural pozzolan for the maximum compressive strength of concrete," Cement and Concrete Research, vol. 34, no. 12, p. 2175, 2004.

[48] A. Çolak, "Characteristics of pastes from a Portland cement containing different amounts of natural pozzolan," Cement and Concrete Research, vol. 33, pp. 585-593, 2003.

[49] P. N. Lemougna, K. t. Wang, Q. Tang et al., "Review on the use of volcanic ashes for engineering applications," Resources Conservation and Recycling, vol. 137, pp. 177-190, 2018.

[50] E. Vejmelková, T. Kulovaná, M. Ondráček, and R. Černý, "Application of natural zeolite as supplementary cementitious material in concrete production," in Proceedings of the CESB 2013 PRAGUE-Central Europe towards Sustainable Building 2013, Sustainable Building and Refurbishment for Next Generations, Prague, Czech Republic, June 2013.

[51] Y. T. Tran, J. Lee, P. Kumar, K. H. Kim, and S. S. Lee, "Natural zeolite and its application in concrete composite production," Composites Part B: Engineering.vol. 165, pp. 354-364, 2019.

[52] D. Jana, "A new look to an old pozzolan: clinoptilolite-a promising pozzolan in concrete," in Proceedings of the International Cement Microscopy Association-29th International Conference on Cement Microscopy, PQ, Canada, May 2007.

[53] K. Narasimhulu, R. Gettu, and K. G. Babu, "Beneficiation of natural zeolite through flash calcination for its use as a mineral admixture in concrete," Journal of Materials in Civil Engineering, vol. 26, no. 1, pp. 24-33, 2014.

[54] G. Külekçi, B. Erçikdi, and Ş. Aliyazicioğlu, "Effect of waste brick as mineral admixture on the mechanical performance of cemented paste backfill," in Proceedings of the IOP Conference Series Earth and Environmental Science, Prague, Czech Republic, September 2016.

[55] F. Cihangir and Y. Akyol, "Mechanical, hydrological and microstructural assessment of the durability of cemented paste backfill containing alkali-activated slag," International Journal of Mining, Reclamation and Environment, vol. 32, no. 2, pp. 123-143, 2018.

[56] L. Dembovska, D. Bajare, I. Pundiene, and L. Vitola, "Effect of pozzolanic additives on the strength development of high performance concrete," Procedia Engineering, vol. 172, pp. 202-210, 2017.

[57] N. Beuntner and K. C. Thienel, "Properties of calcined lias delta clay-technological effects, physical characteristics and reactivity in cement," RILEM Bookseries, vol. 10, pp. 43-50, 2015.

[58] M. Bediako, A. A. Adjaottor, and S. K. Y. Gawu, "Selected mechanical properties of mortar used for masonry incorporating artificial pozzolana," in Proccedings of the Modern Methods and Advances in Structural Engineering and Construction, Zurich, Switzerland, June 2011.

[59] J. S. Mahlaba, E. P. Kearsley, R. A. Kruger, and P. C. Pretorius, "Evaluation of workability and strength development of fly ash pastes prepared with industrial brines rich in and $\mathrm{Cl}^{-}$to expand brine utilisation," Minerals Engineering, vol. 24, no. 10, p. 1077, 2011.

[60] A. Wu, Y. Wang, H. Wang, S. Yin, and X. Miao, "Coupled effects of cement type and water quality on the properties of cemented paste backfill," International Journal of Mineral Processing, vol. 143, p. 65, 2015. 
[61] ASTM D2166/D2166M-16 Standard Test Method for Unconfined Compressive Strength of Cohesive Soil, ASTM International, West Conshohocken, PA, USA, 2016.

[62] ASTM D4404-18 Standard Test Method for Determination of Pore Volume and Pore Volume Distribution of Soil and Rock by Mercury Intrusion Porosimetry, ASTM International, West Conshohocken, PA, USA, 2018. 